\title{
Developing Countries in International Negotiations: How they Influence Trade and Climate Change Negotiations
}

\author{
Sheila Page*
}

\section{Why developing countries need to participate in international negotiations}

Negotiations are becoming an increasingly important part of the international system, with the increase particularly marked for developing countries. Multilateral trade negotiations have existed since the foundation of the General Agreement on Tariffs and Trade (GATT) in 1947, but these negotiations have become more complex and important for developing countries. These negotiations are increasingly presented as being of benefit to developing countries. The climate change negotiations undertaken within the United Nations Framework Convention on Climate Change (UNFCCC) use concepts like "equity" and ask that developed country parties should take the lead in combating climate change. The current Round of world trade negotiations was christened the "Development Agenda" and there is strong pressure on developing countries to use trade activities in development and poverty reduction.

Are these negotiations actually important for poverty and development? Can developing countries participate effectively in these negotiations, and can they obtain benefits from such participation? What lessons can be learnt from past negotiations about whether developing country participation is effective and how it might be made more effective? Can international institutions or donors help? Finally, what are the implications for more extensive and increasingly effective developing country participation in such negotiations for the way these negotiations are conducted?

\section{Poverty effects from trade}

Examination of the relationships among trade, trade policy and poverty shows (Page 2001 and Bird 2003, for an extensive discussion and bibliography) that trade can have significant effects on total income and on its distribution, and therefore on poverty. The direct impact on poverty of particular changes in trade, which may be attributable to changes in trade policy, which in turn may be attributable to negotiating success or failure can be traced, through price, employment and fiscal effects to incomes and then through household analysis, to the income and assets aspects of poverty.

Trade policy, which reduces barriers to trade increases some incomes (and normally reduces others), through changes in the composition of production and in relative prices and perhaps through changes in government income (and therefore spending). This may have a direct effect on poverty (sectoral and household analyses are required). If policy (unlike normal trend changes in trade) creates abrupt changes (losses of a whole sector), the effects may be more severe. More opportunities in trade (through imports or access for exports) are likely to increase national income and may increase efficiency sufficiently to increase growth. This may have direct effects on poverty (the evidence is that it is likely, but not inevitable) and clearly has effects on the potential to reduce poverty, depending on government policy response. Both the macroeconomic and the sectoral and distributional effects are now well studied. 


\section{Poverty effects from climate change}

In other areas of international intervention, the analysis is less well established, but analysis of the relationships among climate change, climate conventions and poverty (McGuigan et al. 2002; Richards 2002) indicates that climate change impacts will be particularly damaging to poor countries, and that some of the measures proposed to mitigate it can have important distributional effects. This is reflected in the increasing prominence of poverty and sustainable development questions in the UNFCCC negotiations.

Climate change is predicted to deepen poverty both directly and indirectly. The direct impacts include the loss of life, livelihoods, assets, infrastructure, etc., from climatic extreme events. The indirect effect is due to the effect on economic growth; continuing climate change variation is predicted to alter the sectoral origins of growth, including the ability of the poor to engage in the non-farm sector, as well as increase inequality, and therefore to reduce the poverty elasticity of growth (ERM 2002). The effects come from:

- Reductions in crop yields in most tropical and subtropical regions due to decreased water availability and new or changed insect pest incidence. Such changes would have a major impact on food security, employment, incomes, and economic growth. For example, one study has predicted a 9-25 per cent fall in net farm revenue in India from a temperature rise of $2-3.5^{\circ} \mathrm{C}$; reductions in crop yields can be expected to lead to localised food price rises.

- Huge displacement of people from coastal and densely populated low-lying areas like the Bangla, Mekong and Yangtze Deltas, while islands like Tuvalu, Kiribati, Anguilla and the Maldives could disappear.

- Exposure of millions of people to new health risks, especially from vector-based diseases like malaria and schistosomiasis, as well as waterborne diseases such as cholera and dysentery. Malnutrition from the reduction in crop yields would increase the severity of these diseases and health impacts are likely to have an effect on growth.

- Climate change will increase the frequency and severity of extreme climatic events.

Poorer developing countries are most at risk, since they are more reliant on agriculture, more vulnerable to coastal and water resource changes and have less financial, technical and institutional capacity for "adaptation".

In principle, the direct effects of trade or climate change on poverty could be redistributed by government intervention. But for countries with limited administrative and fiscal capacity to redistribute income, the type of trade and climate change policy matters for poverty impact.

\section{Can developing countries gain from participating in trade negoti- ations?'}

Two pessimistic views argue that they cannot. If the outcomes of negotiations depend on the balance of power, then no amount of negotiating will make a difference. The predicted outcome can change only if power changes, for example the rise of the EU in the GATT/World Trade Organization (WTO) from the 1950s to the present (Jawara and Kwa 2003). The second cause for pessimism is based on observation. It is argued that developing countries have achieved little or have even lost in trade, climate change and other environmental negotiations.

But in apparent contradiction to these views, developing countries themselves are putting more resources into participation in negotiations. They have proved first that they can modify the outcome, then that they can block a settlement and finally, that they can initiate their own issues. This can be seen clearly from the way that trade decisions have evolved from the 1950s to the present.

There were good reasons why it was not in the interests of developing countries to participate in trade negotiations in the 1950s and 1960s. Inward-orientated development strategies implied that there was little to gain from exports and little to lose (and possibly something to gain) from maintaining tariffs and quantitative restrictions to exclude imports. A country following this strategy should put minimal resources into international negotiations. The GATT negotiations excluded from consideration many of the products of most export interest to them (agriculture and textiles), and networks of trade preferences like that for the ACP (Africa, Caribbean and 
Pacific countries) by the EU or for the Caribbean by the USA gave them better-than-GATT trading terms without negotiation. On most trade rules, they could choose to opt out.

However, by the time of the Uruguay Round (1986-94), much more was at stake for developing countries. They (and their development advisers) were emphasising export promotion and agriculture and textiles were on the negotiating table. Developed countries were pressing for access to developing country markets and also sought a substantial number of agreements on issues such as intellectual property, customs valuation, anti-dumping and the use of subsidies. Critically, the Uruguay Round established the "single undertaking". Countries could no longer pick and choose which parts of the agreement they would sign up to. That they had to sign up for the whole agreement raised the stakes considerably.

By the end of the Uruguay Round, some progress had been made on both agriculture and textiles and clothing. While developed country agricultural protectionism remained, the tariff, subsidy and quota arrangements were brought under WTO discipline. The long-standing (from the early 1960s) restrictions on developing country exports of their principal manufactures, textiles and clothing, under the Multifibre Arrangement, were scheduled to be phased out within 10 years.

At the end of the Round, developing countries concluded that those who had gained were those who had participated in the negotiations. While those who had most to gain had participated most actively, the conclusion most non-participating countries drew was that absence was damaging. This is evidenced by the increased resources many formerly non-participating countries have put into missions and by their increased interest in the activities of the WTO, as well as in statements by trade officials.

These factors changed the context for the next Round of trade negotiations, which was scheduled to begin five years later at the Seattle Ministerial in 1999. At this meeting, developing countries' refusal to accept a process from which they had been excluded led to a collapse of the meeting. There were other reasons for the failure, but the developing countries concluded that there had been a further shift in the real balance of power: developing countries could not only negotiate, they could block negotiations.

There was further progress evident at Doha, in
2001. While the broad support for the successful anti-subsidy position in agriculture precludes claiming this as a developing country achievement, there were other clear victories:

1. The meeting accepted that special and differential treatment (allowing different policies by developing countries and requiring different policies towards them) would be "an integral part" of any final settlement; the Uruguay Round had offered only minor adjustments to policy and non-obligatory concessions. ${ }^{2}$

2. Doha also extended the times for Least Developed Countries to comply with subsidy and intellectual property rules. These issues were accepted at Doha in spite of initial strong opposition by developed countries, indicating that these countries thought they were a necessary part of any bargain.

3. The Doha meeting also showed that developing countries could initiate new negotiating issues. Developing country positions included not only the issues of traditional concern to them (agriculture, non-tariff barriers, tariff discrimination and escalation) and opposition to the new 'developed country issues' (investment, competition policy, labour), but also new subjects for the agenda: the importance of infrastructure for trade, linkages between debt and trade, and the nature of commodity markets. The developing countries thus had broadened the definition of "development issues" beyond that suggested by those developed countries advocating a "development round": technical assistance and liberalising trade. One of these new agenda items was approved at Doha: a new working group on 'the relationship between trade, debt and finance'.

At the mid-term ministerial meeting to review progress on Doha, at Cancun in September 2003, developing countries placed two new issues on the agenda: the specific effect of US agricultural subsidies on cotton on Mali, Chad, Benin, and Burkina Faso and the effect of general liberalisation on the few countries, which are highly dependent on preferences and other types of special access (notably the Least Developed Countries and those with quotas for sugar). Both had been recognised in general terms, but targeted and quantified studies (Goreux 2003; ILEAP 2003; IMF 2003) of the effects of specific measures on specific countries were used to bring 
them to prominence. Both issues were introduced into the revision of the draft final statement and both are now clearly on the international agenda. The collapse of the meeting, however, was probably the result of a decision by the USA, not the opposition of the developing countries.

\section{Why have developing countries become more effective in trade negotiations?}

Given the undoubted power of the leading developed countries, how has it been possible for developing countries to have made such progress in trade negotiations? The answer appears to be that in multilateral negotiations, the bargaining power of the strongest nations is limited by the need for agreements to be finalised. If a powerful country wants market access and if this requires action by another country, it must secure its agreement. The studies on negotiations and country experiences (Page 2002; Bojanic 2001a,b; Durrant 2002; Hess 2001) identify when small countries have been able to turn this potential into reality by negotiating effectively and changing outcomes.

\subsection{The importance of experience}

Developing country trade negotiating capacity has clearly benefited from the experience of successive trade rounds. In 1986, at the beginning of the last trade negotiations, developing countries did not realise that the open-ended or vague commitments in the agenda could become significant agreements. Services, Trade-Related Aspects of Intellectual Property Rights (TRIPs) - patents and copyright and the single undertaking were all in the negotiating mandate, but their implications were not clear. At the Seattle ministerial meeting in 1999, which had the task of setting the agenda for the following round, a detailed rejection of points in the agenda by developing countries led to failure; at Doha (2001) developing countries moved beyond rejection alone and were active in setting the agenda, realising that they could not remain outside any negotiation, however irrelevant or unimportant it might seem initially. At Cancun, they scrutinised the proposals in detail.

Developing countries are now able to develop more sophisticated positions, for example, on the issue of services. In the Uruguay Round they began with little information about their own interests. By the time of the Doha meeting, 15 years later, there was greater confidence and precision in offers and positions.

The emergence of better-informed policy positions in the course of the Uruguay Round discussion of services and the improvements seen in competence of individual country delegations in the Round suggest that long negotiations can help to produce informed outcomes for new subjects or new participants. At the beginning, Brazil and India were almost the only countries to be effective: they had been active in the previous, Tokyo, Round. During the Uruguay Round, Argentina, Bangladesh and other Asian and Latin American countries started to be active. At the Seattle conference and between then and the Doha conference (2001), the countries which had been inexperienced participants in the Uruguay Round began to plan a more active role, and even the African countries started to define and present negotiating positions (more than half the position papers before Seattle and Doha were from developing countries). The countries that had participated without experience and with little success in the Uruguay Round, were now seeing their second Round and started to share the advantages of the "old" developing country activists. The pressure for limited duration Rounds may not be in the interests of developing countries. ${ }^{3}$

In the preparations for the Cancun meeting, again all countries, including the least active negotiators among the Least Developed Countries, presented positions and participated in meetings of groups, in particular the African Union and the Least Developed Group. This greater participation was reflected in the way the negotiations themselves were organised. The groups where able to choose their own representatives to the consultations by subject and smaller, "Green Room", meetings, ${ }^{4}$ rather than being selected by the Chair of the meeting (as in the past). New countries (e.g. Ghana for agriculture) started to come to prominence.

\subsection{The role of alliances in strengthening negotiating positions}

Since the Uruguay Round, the growing importance of regional trading groups among developing countries has led to an interest in using these as negotiating blocs, and some of the negotiating positions have been defined by region. However, only the EU negotiates as a bloc for multilateral trade rounds. Not even the customs unions like 
CARICOM (Caribbean Community), Mercosur, SACU (Southern African Customs Union) and COMESA (Common Market for Eastern and Southern Africa) negotiate as blocks. ${ }^{5}$ The Free Trade Areas (FTAs) have not shown any interest in joint negotiation, even when (as with SADC and some other ACP regions) there are proposals to transform them eventually into customs unions. This suggests that most of the regions are seen primarily as a way of increasing the integration of members within the region members, with the need to have a common external position accepted as a (perhaps inconvenient) consequence. They have not been formed, not as negotiating blocs to strengthen their position in the world economy. It means that the ACP regions (except, to a limited degree, CARICOM) have no policy basis or institutional structure for the negotiations they are expected to undertake with the EU under the new ACP-EU proposals for free trade areas between regions and the EU. This point is discussed further below.

Instead, common characteristic groups (e.g. Least Developed Countries or the small island states) as well as exporters of particular commodities such as sugar have emerged as more important in formulating positions than the FTAs. At Doha, the Least Developed Countries secured a range of special mentions, and avoided any expressions of opposition to special treatment for them; the small economies got a 'work programme to examine issues'. Unlike formally established regional groups among developing countries, the Africa Group was effective in mobilising support for the developing countries' own initiative issues, notably debt. This group, which includes the various regional trade groups, and which is more like the common characteristic groups than the formal regions, started to meet in the runup to the Seattle meeting, and has become increasingly important in coordinating positions.

Another group, which started to emerge in Seattle, is a much more fluid group of leading developing countries. The long-established leadership of India and Brazil was extended to include Egypt, Nigeria and South Africa. All have a common interest in continuing liberalisation in the WTO context, although with very different (and potentially opposed) interests in particular elements of the negotiation. Their interests are also in some respects very different from those of the smaller economies (where trade is a much more important part of the economy), so that they are not seen as (although they may see themselves as) leaders of the old developing country alignment. All could be seen as leaders of regional groups: Mercosur, Northern Africa, SAARC (South Asian Association for Regional Cooperation), ECOWAS (Economic Community of West African States) and SADC (Southern African Development Community). Brazil and South Africa, at least, have acted informally as reporters-back to the Latin American and Southern African countries respectively in the WTO negotiations. Other smaller countries, such as Jamaica, Mauritius and Bangladesh, have also emerged as frequent leaders in taking positions, chairing committees, etc. Where there are general developed-developing country issues (special and differential treatment, the inclusion of the new issues like investment and competition policy), agreement from this set can constitute a developing country position, although on more specialised questions, they are not representative.

At Cancun, there was the first semi-formal recognition of groups among the developing countries (and of a new group among the developed: the G10, those least willing to liberalise agriculture, led by Switzerland). Countries presented positions saying that they were on behalf of groups like the Africa Group and Least Developed Countries and the Chairs of the groups were chosen to represent developing countries in both the informal consultations on various issues during the conference and in the Green Room in the final stages. There were explicit arrangements for them to "report back" to their "constituencies". During the negotiations, individual groups had procedures for regular consultation and consideration of positions and arranged negotiations with other groups to arrange common positions.

A new group, the G20 (or now G20+), of developing country agricultural exporters (but including the traditional leaders, Brazil, India, South Africa, Eygpt, now joined by China), emerged in the weeks before the conference, and acted much more formally together than the others. It secured the two symbols of "recognition" at the talks: representation in consultations the Green Room and a meeting room of its own. Its emergence, combined with the emergence of the G10 on the other side of the agricultural negotiations, and the strong divide between the developed and developing countries on the developed country 
proposal to introduce regulation of investment, competition policy, government procurement and trade facilitation, the "Singapore issues", meant that the Cancun Ministerial was perhaps the first meeting since the 1970s where the divisions were almost uniformly between developed and developing countries. The divisions within each grouping were less important. The EU-ACP alliance of Doha, the Cairns alliance of all efficient agriculture countries of the Uruguay Round and other developeddeveloping alliances were no longer important.

Common characteristic groups come together for a general agenda, not just a single negotiating topic, and therefore have to negotiate and settle differences of interests among themselves. Interest groups, like the G20 for agriculture or sugar exporters only work together on that issue. Common characteristic groups therefore, may be less likely than are exporter-groups to survive detailed national assessment of interests.

\section{Climate change negotiations}

The same development of negotiating capabilities through both experience and the formation of developing country interest groupings has yet to be seen in negotiations on climate change. In these negotiations, some conditions remain less favourable (Richards 2001, 2002). While the risks to developing countries are becoming clear, the potential gains from the current negotiations are less so; the choice of how strongly to participate is therefore more difficult. And there is less pressure from developed countries for developing countries to participate: wealthy countries have little to gain from an international regime, because they are geographically less vulnerable.

\subsection{Less experience}

Climate convention negotiations began in the 1990s, a period when developing country participation and separate treatment were accepted from the beginning. At the annual meetings, developing countries (notably Brazil) have begun to make proposals, but they have not been able to alter any outcomes of the negotiations. A fundamental disagreement remains over whether the principle of equity in responding to climate change implies that all countries must bear some responsibility for reducing emissions (broadly speaking the Northern view), or that the Northern countries that are responsible for most emissions should bear most of the burden of responding to the challenge (broadly speaking, the Southern view). ${ }^{6}$

Developing countries have maintained a fairly consistent position. Most have continued to oppose joining in any actions to reduce emissions, on the grounds of fairness. Most have argued that developed countries should reduce emissions, rather than achieving their targets through trading emissions permits and the other offset mechanisms in the Kyoto Protocol. Countries have thus tended to take 'defensive' strategies, and to focus more on issues and principles than interests. This has precluded active participation in the negotiations and allowed developed countries to settle for weaker targets.

The new perception (IPCC 2001) that climate change impacts are now irreversible given the time lag between mitigation actions and their effect on the atmospheric concentration of greenhouse gases, and will be most severe on poor people in poor countries, has changed developing country attitudes. For developing countries, the climate change "adaptation" agenda has become as important as the "mitigation" agenda.

The commitment by developing countries in climate change negotiations to not taking on obligations is more like the 1970s developing country position in trade negotiations, of wanting a separate regime, than the 1980s and 1990s model of active participation, offering concessions in return for demands. One reason for this is that those developing countries which have most to gain from climate change negotiations (or most to lose from inaction) are determined by geography and climate; they are not necessarily the most developed and ready to negotiate, while in trade it is (in general) the more advanced countries that have seen benefits from negotiations and have participated earliest and most extensively. Except in the most vulnerable countries (and not even in some of these), climate change has not risen in domestic policy priorities as trade has, since the 1990s.

Overall, most developing countries thus seem still at the post-Uruguay or Seattle stage of feeling too disadvantaged and excluded to participate effectively. The disadvantages mentioned by countries are the same as in trade: small and inexperienced delegations, lack of national research support, lack of familiarity with how negotiations are done. Many countries have still not identified a strong interest in the outcome of climate change negotiations, and therefore choose to devote few 
resources to them, while there is little pressure on them to meet climate objectives: they are marginal to the major commitments being made on greenhouse gases.

\subsection{Weaker alliances}

In the climate change negotiations, although the G77 plus China Group remains the most important developing country coalition, there are important differences in negotiating positions and interests. OPEC (oil exporting) countries have not wanted strong mitigation of climate change, while the Association of Small-Island States (AOSIS) grouping wants strong action. Countries with serious climate change concerns, but with a possibility of obtaining payments in the Clean Development Mechanism Market (CDM-CER), have mixed interests. As in the trade negotiations, this led some to leave the common-characteristic groups. These are, in any case, less clear and weaker in climate change, although the Least Developed Countries and the Africa Group have been active, indicating that these are now more than ad hoc alliances for the WTO negotiations. The all-developing country position may remain stronger than in trade because there are fewer sectoral interests of the type found in trade negotiations and perhaps also because of the stronger commitment by most developing countries to the principles and the defensive position. AOSIS is emerging there as well as in trade as one of the best-organised groups. There are occasional developing-developed country alliances, but some criticise these as 'divide and rule' tactics by the developed countries.

In climate change, the developed-developing divide has been more persistent. The North tends to place more emphasis on disaster prevention and preparedness. The South argues that given the irreversibility of climate change impacts, this is inadequate for short-term threats; it places more emphasis on disaster relief.

\section{Challenges for future negotiations}

The growing effectiveness of developing countries faces three potential problems:

- how to integrate the parallel increase in the effectiveness of national pressure interest groups into the negotiations;

- how to adapt the multilateral system to take account of the new participants; and
- whether developing countries can use their new skills effectively in the growing number of bilateral North-South negotiations.

\subsection{The role of the private sector}

In the Uruguay Round, the developed countries had faced lobbying from industrial interests, particularly on the "new" issues - services, intellectual property, and rules. However, they had been able to use private industrial groups and firms to provide the expertise which was not available within the government, increasing their understanding of the issues at stake and the effectiveness of their negotiating stance. This example convinced some developing countries that the advantages of having an informed private sector more involved in negotiations outweighed any disadvantages from potential opposition or interference. Most developing countries lacked not only the industry groups, but also any formal mechanisms for their participation. This meant that there was neither support from private industry knowledge nor commitment to the results. Negotiations were entered into without studying the implications for key economic sectors and negotiating positions were of a general, "sweeping" or political nature, not backed up by solid evidence. There were inadequate consultations with both the private sector and civil society.

But after the Uruguay Round this changed. The greater coverage of the agreement meant that domestic interests found themselves affected by new rules (TRIPs, standards, etc.). Better communications meant that the protests in the more informed countries (not only in developed countries, but also in India) were heard in the less active. And the WTO, UNCTAD, and bilateral donors, for the first time prepared a major campaign to inform all interests in even the inactive countries of the results and their implications. Governments therefore faced not only their own new perception that if they participated actively, they could influence the result, but also strong and informed external pressure to act more effectively in the future. This strong private sector lobbying and the resulting pre-meeting agreements on formal national positions, however, can make any compromises or alliances more difficult. Delegations without national support or interest had had considerable freedom to act, to form alliances, and to accept exclusion from decisions.

Cancun illustrated the consequences of these 
changes. Developing countries followed the example of the developed countries and brought not only government officials from ministries other than trade (e.g. agriculture and health for negotiations on intellectual property), but representatives of their major national interests. These had side meetings with their counterparts on the margins of the main negotiations (e.g. in sugar), but also participated directly in formation of positions and reactions to positions taken by others in the negotiations. This is likely to have made it more difficult for governments to alter their positions and trade off different national interests. The format of the meeting, with the prominence given to official ministerial statements of position and, in many cases, repeated endorsement of group positions taken in advance of the meeting, also made compromise or flexibility difficult to arrange.

Delegations with a clear mandate, from their own government, perhaps in consultation with economic or other interests, may have much less flexibility to defer to the more powerful or to form alliances with other opponents. They must demonstrate that they participated actively. Deadlock may not be inevitable, but may now be more likely, and certain negotiations will be harder and longer. If the refusal of the USA to compromise on agriculture had not ended the meeting prematurely, these rigidities might have prevented agreement.

\section{How the international negotiations must adapt}

In GATT negotiations prior to the Uruguay Round, there were no formal procedures for negotiations and consultations. In the early rounds, the USA dominated proceedings and by the 1970s, US-EU bilateral meetings were the forum in which agreements were reached. While the Uruguay Round had seen some increase in formal negotiations, supplementing, if not replacing the EU-US bilateral meetings of previous Rounds, there was still a heavy emphasis on "informal" meetings. These consisted of ad hoc groups, with virtually no rules of procedure or specification of who should attend. These do not only become increasingly impractical with more and more inexperienced participants, but do not offer the official evidence of participation which countries now require to be accountable to interested and informed national groups.

In the final months before the Seattle meeting in 1999, new procedures were introduced so as to include all countries, at least occasionally, in the consultations on the agenda for negotiations. This followed what had been established as the normal "informal" procedure in negotiations in the Uruguay Round, of small committees, which were effectively open to anyone who was known to have an interest. Countries which were too new or small (or absent from Geneva and the negotiations) to be known to have an interest were not always included, but it avoided official discrimination among countries, and was accessible to the active countries that might challenge their exclusion.

In 2001, the WTO and its major members still supported informal consultations. Although some developing countries continued to question their legitimacy, two successive competent chairs of the General Council were able to engage and be trusted by most of the delegations. This, together with a general desire to avoid a second failure, meant that the system avoided breakdown, but it remained weak.

In 2003, developing countries proposed reforms to ensure that both draft papers and procedures were decided by official committees (WTO 2003), but this was not adopted. At Cancun, the informal procedures were made as formal as possible, in that the official representatives of the informal groups were treated as their representatives. But the absence of any formal means for the groups to adjust their negotiating positions was one reason (combined with the absence of, first, as competent a chair of the meeting as at Doha, and second as compelling a reason for the developed countries to compromise as the $9 / 11$ attacks), that it was not possible to secure agreement. The presence of a large number of interests, within countries and among countries, now increasingly clearly asserted, means that if country representatives and then the WTO are to represent these interests and be accountable back to them, then more formal structures will be necessary.

As suggested in the evidence from the Uruguay Round, the compression of the negotiations also made it more difficult for countries to consider the consequences of new offers, analyse their impact on national economies, and rearrange alliances. The structure of the meetings, with consultations on any new positions among groups of up to 60 countries, many with more than one interest represented within the country, requires more formal structures within the groups and/or more than the one hour typically available for consultation 
and consideration of positions.

Similar problems can be expected in the climate change negotiations. These also rely heavily on informal meetings during negotiations. If developing country participation there becomes more active, informed and differentiated according to the differing interests within the developing world, then these informal negotiating procedures will not be adequate.

\subsection{Transferring the new skills to other negotiations: the Africa, Caribbean and Pacific Countries (ACP) experience}

It has been argued here that developing countries have been able to participate more effectively in recent trade rounds. Can the lessons learnt from the negotiations be applied to bilateral negotiations? This issue was examined in the case of the negotiations between the EU and its associated ACP countries. In this case, there is much less evidence of serious participation by developing countries and no sign of success for them (Solignac-Lecomte 2001). Until 2000, trade relations were entirely non-reciprocal: the EU established preferences, but did not require specific concessions from the ACP countries, so there was no opportunity or need to negotiate. However, the EU's 1998 proposals to change from preferences to reciprocal free trade required negotiation for the first time. The countries have not yet adjusted to this change and were unable to mobilise opposition to the new regime. They were not able to protect the special commodity arrangements (e.g. sugar). They did not secure consultation in the face of new arrangements with other countries (Eastern Europe, Mexico, Chile, South Africa, etc.) which have reduced their margin of preference.

This failure raises some important questions. As some of the countries in the ACP are among those active in the WTO, and the same people were frequently involved in both sets of negotiations, why was there such a difference in negotiating ability and outcomes? The main reason for the difference appears to be the fact that when negotiating with the EU, the role of the EU as donor was emphasised as part of the same negotiation. ACP negotiators could not simultaneously demand equal treatment as trading partners and beg for aid.

The nature of ACP-EU negotiations also precluded the development of effective alliances among the ACP countries. The ACP are all small countries, and almost all of them are among the more inexperienced in negotiations, so there are no actors like India and Brazil to lead coalitions and provide research and support. The EU decided that the appropriate division would be by regional group, not by common characteristic; it divides the Africa Group into four to five regions. Although it subsequently offered a different trading arrangement to the Least Developed, it has not accepted this as an appropriate division among ACP countries for the negotiations (there are Least Developed in all the chosen regions, so all have to deal with the different interests). Some sectoral interests are trying to coordinate (notably sugar exporters), but the pattern of negotiations can be considered as both an explanation for weak ACP effectiveness in negotiation (they do not have the normal alliances available), and also an example of it (they have not resisted the EU's division effectively).

If the failure of multilateral negotiations, in trade at Cancun, in climate change over the Kyoto Protocol and in other subjects, reinforces the trend towards bilateral negotiations, the experience of the ACP (for which there are parallels in Central America negotiations with the USA, for example) suggests that developing countries, particularly those which are weak and inexperienced, will be at a greater disadvantage in these than in multilateral. For developed countries, avoiding the new alliances of developing countries in the WTO is an additional reason for preferring the bilateral rounds.

Is this likely to become a substitute for the WTO (and other multilateral fora)? For small developing countries this is a possible and potentially serious problem. However, the larger countries have shown more ability in these negotiations as well. Mexico chose to negotiate NAFTA (North American Free Trade Agreement), and then preserved its access to more diversified markets by negotiating parallel agreements with the EU and (now in progress) Japan. South Africa negotiated first with the EU and is now negotiating with the US. Brazil, with or without the rest of Mercosur, is also looking in both directions, and its negotiations with the US after Cancun also failed. The risk is an unstable system of some arrangements imposed by developed countries on their satellites and interlocking agreements with the middle-level countries (with all the disadvantages of trade diversion and inefficient rules of origin).

\section{Conclusions}


Some developing countries now believe that they have clear interests in the results of international negotiations. Many have become convinced that trade can have significant effects on their total income and on their development. Most believe that the effects of climate change will be particularly damaging to poor countries, while some of the measures proposed to mitigate it could provide significant financial benefits. Although trade policy and climate change policies may not be the most important or direct policy instruments against poverty, for countries with limited administrative and fiscal capacity, the outcomes of trade and climate change negotiations matter for poverty.

Having identified interests in the negotiations, developing countries have attempted to participate. By participating, they have learned some lessons that are making them more effective:

- Participation is working best in the longest established negotiations (WTO, not climate change), with the broadest range of allies and least obvious dependency (WTO, not ACP).

- It works best when and where developing

and institutions, in information about how others negotiate effectively, and in reform of some procedures of the international institutions which work against weak or inexperienced countries.

\section{Notes}

* This article is based on the results of a study, 'Effective Participation by Developing Countries in International Governance, Institutions and Negotiations'. The papers in the Bibliography by Alan Bojanic, Nigel Durrant, Peter Frost, Richard Hess, Michael Richards, Henri-Bernard Solignac-Lecomte, as well as by the author were prepared for that. I am grateful to the UK Department for International Development (DFID) for financing the research project, which was part of the Globalisation and Poverty Programme. I am grateful to John Humphrey for his comments and suggestions throughout the project. For further information on this project, please contact Sheila Page at: s.page@odi.org.uk. For further information on the Globalisation and Poverty Programme, see www.gapresearch.org

1. These issues are also being explored in the research project 'Developing Countries and the Trade Negotiation Process', under the direction of John S. Odell, University of Southern California, in association with the University of Geneva. countries can perceive their interests most clearly. In climate change, there are still complaints that developing countries are excluded and have little voice. At Doha however, developing countries' participation was reasonably effective (small, weak countries will never take control from the larger).

- At Cancun, developing and some developed countries both blocked the agreement; the developing countries again secured small initiatives. But many countries have not yet made the transition to interest-based, effective participation, and the institutions have not yet been changed to be appropriate for more players with more complex interests.

Countries need domestic capacity to coordinate official and private objectives in the negotiations, to be able to prepare an informed position, and to be able to negotiate and justify the outcome to national interests. But this in turn can make negotiations more difficult. A shift to bilateral negotiations will weaken developing countries' effectiveness, particularly for the smallest. These conclusions suggest some areas where assistance can help: in national policy capacity

For further information see www.ruig-gian.org/conf/ negocecommprogpapers.htm

2. The issue of special and differential treatment was the subject of a recent IDS Bulletin (Stevens 2003).

3. Negotiating experience was also acquired in the regional trade negotiations in which most Latin American, Caribbean and African countries had participated by 1999. This provided experience in identifying negotiating issues and allies and, in negotiation itself. These negotiations also generated analysis and data, on trade rules, trade patterns and interests, useful in the multilateral negotiations

4. There are no formal procedures for WTO Ministerial meetings. The custom is for the chair to designate "friends" to hold consultations on the principal issues, partly open, partly with the principal interest groups, and then to consolidate the positions in a "Green Room" meeting of principal countries. At Seattle, these were the largest countries, plus countries which the chair chose to represent the others.

5. The CARICOM countries have taken some steps towards negotiating trade regionally. They agreed jointly on the tariff that was eventually bound, and in 2003, they adopted a common approach on services, and as a group 
they are switching from country to regional offers and requests.

6. These issues are discussed in more detail in Richards (2002).

\section{References}

Bird, K., 2003, 'A framework to analyse linkages between trade policy, poverty reduction and sustainable development', ODI Working Paper

Bojanic, A., 200la, 'Bolivia's participation in international trade negotiations', ODI Working Paper, www.odi.org.uk/iedg/participation_in_ negotiations/bolivia_trade.pdf (accessed November 2003)

Bojanic, A., 2001b, 'Bolivia's participation in the UN framework on climate change', ODI Working Paper, www.odi.org.uk/iedg/partici$\mathrm{p} \quad \mathrm{a} \quad \mathrm{t}$ i $\mathrm{o} \quad \mathrm{n} \quad \mathrm{i} \mathrm{n}$ negotiations/bolivian_climate_change.pdf (accessed November 2003)

Durrant, N., 2002, 'Guyana's participation in multilateral and regional trade negotiations and the United Nations Framework Convention on Climate Change (UNFCCC)', ODI Working Paper, www.odi.org.uk/iedg/participation_in_negotia tions/ guyana_climate_change.pdf (accessed November 2003)

ERM (Environmental Resources Management), 2002, 'Predicted impact of global climate change on poverty and the sustainable achievement of the Millennium Development Goals', Report prepared for DFID by Environmental Resources Management, ref. 8409, London

Frost, P., 2001a, 'Zimbabwe and United Nations Framework Convention on Climate Change', ODI Working Paper, www.odi.org.uk/iedg/ participation_in_negotiations/zim_un_climate.pdf (accessed November 2003)

Frost, P., 2001b, 'Effective participation by developing countries in international governance, institutions and negotiations: Zimbabwe and the UN Framework Convention on Climate Change', Working Paper, published in Zimbabwe

Goreux, L., 2003, 'Préjudices causés par les subventions aux filières cotonnières de LAOC', Report for AOC, April

Hess, R., 2001, 'Zimbabwe case study on trade negotiations', ODI Working Paper, www.odi.org.uk/iedg/participation_in_negoti- ations/zimbabwe_ trade.pdf (accessed November 2003)

ILEAP (International Lawyers and Economists Against Poverty), 2003, 'Agricultural products - modalities', Negotiation Policy Brief 2, Working Draft, September www.ileapinitiative.com/pages/ agricultural_modalitiessept03.pdf (accessed December 2003)

IMF (International Monetary Fund), 2003, 'Financing of losses from preference erosion notes on issues raised by developing countries in the Doha Round', Report for WTO, WT/TF/COH/14, February

IPCC (Intergovernmental Panel on Climate Change), 2001, Impacts, Adaptation and Vulnerability. Contribution of Working Group II of the Intergovernmental Panel on Climate Change to the Third Assessment Report of the IPCC, New York: Cambridge University Press Jawara, F. and Kwa, A., 2003, Behind the Scenes at the WTO: the Real World of International Trade Negotiations, London and New York: Zed Books

McGuigan C., Reynolds R. and Wiedmer D., 2002, Poverty and Climate Change: Assessing Impacts in Developing Countries and the Initiatives of the International Community, Consultancy Project for the Overseas Development Institute, London School of Economics, www.odi.org.uk/iedg/ lse.report.pdf (accessed November 2003)

Page, S., 2002, 'Developing countries in GATT/WTO negotiations', ODI Working Paper, www.odi.org.uk/iedg/participation_in_negotia tions/gatt_wtonegotiationsfeb2002.pdf

Page, S., 2001, Trade and Climate Change: Implications for Poverty and Poverty Policy, 31 March, London: Overseas Development Institute

Richards, M., 2002, 'Poverty reduction, equity and climate change: global governance synergies or contradiction?', ODI Briefing Paper, London: Overseas Development Institute

Richards, M., 2001, 'A review of the effectiveness of developing country participation in the climate change convention negotiations', Report for ESCOR Research Programme, Department for International Development (DFID), London: Overseas Development Institute, www.odi.org.uk/ iedg/wps_intro.html (accessed November 2003) 
Solignac-Lecomte, H., 2001, 'Effectiveness of developing country participation in ACP-EU negotiations, ODI Working Paper, www.odi.org.uk/iedg/participation_in_negotiations/acp_eu.pdf

Stevens, C. (ed.), 2003, 'Special and differential treatment in terms of trade', IDS Bulletin, Vol 34 No 2

WTO (World Trade Organization), 2003, Proposals for Improving the Decision-Making Process in the WTO Before and at the Fifth Ministerial Conference, 14 August, WT/GC/W/510 